\title{
Role of Immigrants in the Labor Force Across Four Leading Robot Countries
}

\author{
I. Banevičienè and V. Kumpikaitè-Valiūnienè
}

\begin{abstract}
Robots is one of the attributes of Industry 4.0. The implementation of industrial robots is an indication that country is reforming its industry to meet new immerging requirements; however, the changes in industry create new workforce roles that test the countries readiness for industrial transformation. We analyze four countries that has the most industrial robots' implementation in the world - Singapore, Rep. of Korea, Germany and Japan - with respect to how they are dealing with filling in the immerging roles with skilled and high-skilled workers. The analysis showed that all countries experience shortage of workforce, but there is no pattern in how they are filling in the gaps.
\end{abstract}

Index Terms - Industry 4.0; Robots; Skilled employees.

\section{INTRODUCTION}

Concept of Industry 4.0 originated in Germany in 2011 as proposal to use high-tech strategies in development of Germany's economy [1], [2]. It spread around the world creating Fourth Industrial Revolution. Both terms are used interchangeably depending on the part of the world and describe the main evolving processes of current economy and is a base for forecasting future industrial developments. The defining features of Industry 4.0 are digitization, optimization, and customization of production; automation and adaptation; human machine interaction (HMI); valueadded services and businesses, and automatic data exchange and communication [3], [4]. Robots play an important role in industry 4.0 as they can complete tasks intelligently, with the focus on safety, flexibility, versatility, and collaborative [5].

According to recent research by [6], it is indicated that by 2020 Europe could lack some 825,000 digital know-how specialists. While a skill gap as well as a gap in willingness to adjust to the skill requirements to Industry 4.0 is much greater [7]. There are basically three ways to increase the availability of Industry 4.0 skills: 1) Increase participation by parts of the labor force in Industry 4.0 that are not in it at present, 2) Increase the provision of training and education, 3) Through immigration, which could be indicated as the shortest way to gain missing employees.

Therefore, in this article we analyze what is robot concentration in different countries and how that correlates with immigrant density in that country.

Published on May 25, 2020.

I. Banevičienė, Laney College, Oakland, USA.

(e-mail: banirma@hotmail.com)

V. Kumpikaitè-Valiūnienè, Kaunas University of Technology, School of Economics and Business, Lithuania.

(e-mail: vilmante.kumpikaite@ktu.lt).

\section{ROBOT CONCENTRATION BY THE COUNTRY}

According to International Federation of Robotics, in 2018, 5 countries that implemented the most industrial robots are China 154.000, Japan 55.200, United States 40.400, Rep. of Korea 37.800, and Germany 26.700 [8] (Figure 1).

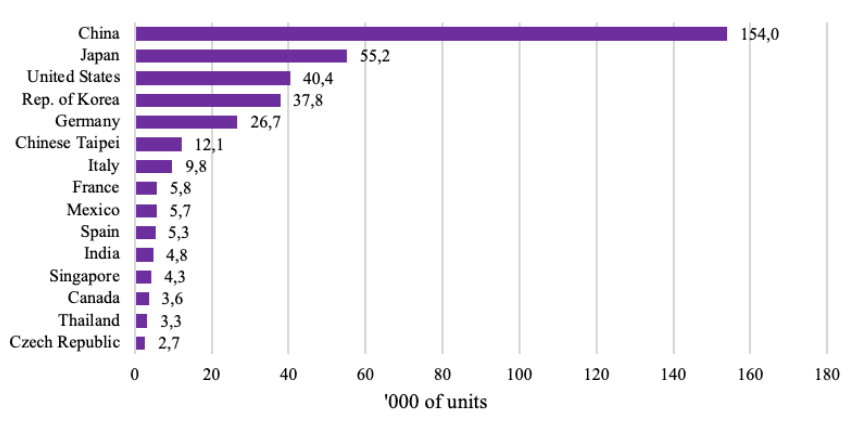

Fig. 1. Annual installation of industrial robots 15 largest markets 2018

[8].

However, absolute numbers are misleading as number of citizens and employees are very different in these countries and do not represent the real picture.

Average number of robots is the highest in Europe and reaches 114 unites, respectively 99 in America and 91 in Asia with total 99 robots average in the world [8].

Analysis of Robot density in the manufacturing industry in 2018 shows that Singapore and Rep. of Korea are clearly

leading countries in robot installation per 10.000 employees following by Germany and Japan far behind in 3rd and 4th places, whereas the United States is in 8th place and China - 20th [8] (Figure 2). Following four leading countries are taken for further analysis.

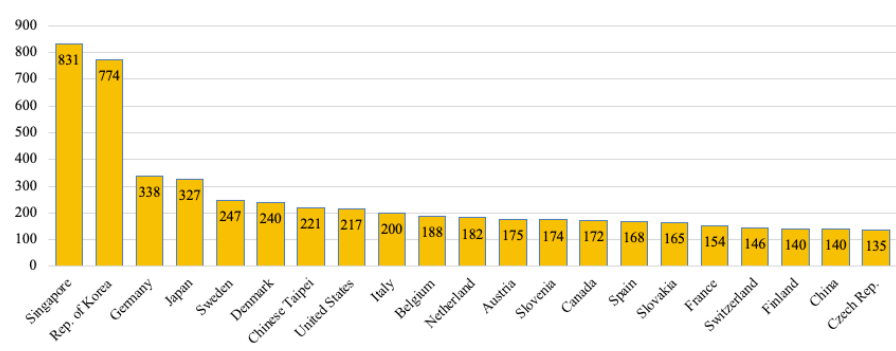

Fig.2. Robot density in the manufacturing industry 2018 [8]

\section{IMMIGRANTS IN LEADING ROBOT IMPLEMENTING COUNTRIES}

We combined the number of robots per 10.000 employees with immigration data into Figure 3 . It shows different 
patterns. Singapore is a leading country of robots and in immigrants. However, the South Korea, having almost the same amount of robots per 10.000 employees as in Singapore have just $3.4 \%$ of immigrants. It is a similar situation comparing other following countries Germany and Japan having similar amounts of robots. Germany has $14.8 \%$ of immigrants and Japan just $1.61 \%$. Every country is presented in more details bellow.

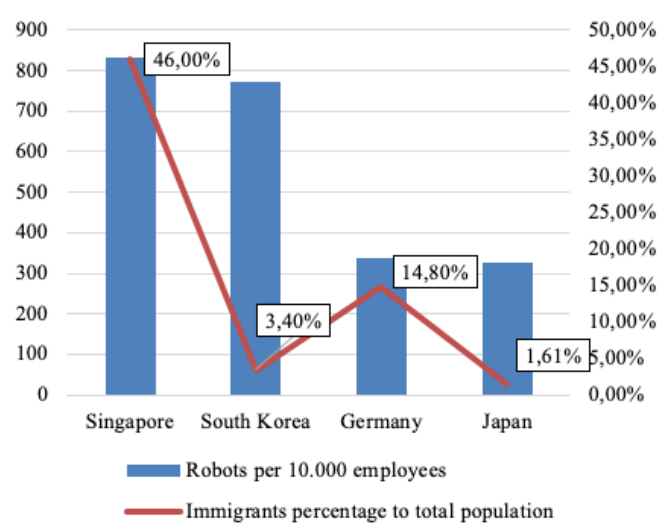

Fig. 3. Correlation between number of robots per 10.000 employees and percentage of immigrants per total population [8], [9].

\section{A. Singapore}

Singapore is a leading country in implementation of industrial robots. It has 831 robots per 10.000 employees [8]. Singaporeans are among most skilled and educated workers in the world; however, decades long fertility regulations led Singapore to experience native-labor shortage [10], [11]. Therefore, it needed to fulfill labor shortage by immigration and now Singapore has $46 \%$ of foreign-born population [12]. According to United Nations, Singapore has more than 2.5 million foreign-born population that are mainly from only few countries of origin: Malaysia, China, Indonesia, India, and Bangladesh [9]. The inflow of immigrants into Singapore is strictly regulated by available job quotas. There are three main categories of work permits that are defined by salary, education and complexity of work. Only S-Pass and E-Pass permits allow high-skilled work, to bring relatives and give eligibility to become permanent Singapore resident. Workpermit holders are migrant workers who are not allowed to seek permanent residency or marry Singaporeans [10], [11], [13], [14]. Therefore, as working with the robots requires considerable skills and education. Only S-Pass and E-Pass holders would be allowed to work directly with the robots and they amount for one third of all immigrant workers.

As a country, Singapore is heavily investing into its people to help them to reach training goals for opening new roles in Industry 4.0. Second-skilling is a practice that is funded by the government to allow its citizens to train for additional skill set in case he/she wants to change the jobs in the future or would be able to find another job if current job is lost [15], [16]. However, only the citizens of Singapore are eligible to take advantage of this Government program.
Summing up, the immigrant population is the first and foremost for filling in the gaps as needed in Singapore labor-markets.

\section{B. Rep. of Korea (South Korea)}

South Korea is the second leading country for implementation of industrial robots. It has 774 robots per 10.000 employees [8]. As opposed to Singapore, South Korea is mostly relying on its citizens to work with the robots and all other jobs as the country historically is monocultural [17]. Only during the last 20 years monocultural approach is changing as country's demographic situation led to a point that South Korea's forecast is for it to not have enough workforce to keep up with the rising economical needs. Centuries of fertility restrictions led to rapidly aging population, fertility rate in South Korea is the lowest in the world - only 1.1 children per woman, and women are choosing to not have family or any romantic relationship in favor of having independent lives and careers [18], [19].

According to United Nations, in 2015 only little over 1.3 million of foreign-born population were registered in South Korea [9], accounting for less than $3.4 \%$ of total population. The major groups of immigrants are from China and Vietnam [9]. Even though the immigration into South Korea is growing, the education level of immigrants is much lower than Koreans, especially young generation. Therefore, immigrants account for only a marginal share of professional workers in South Korea's labor force [20]. Even though country is a leading implementer of industrial robots, it is not relying on immigrants to work with them.

\section{Germany}

Far below Singapore and South Korea, Germany is the third country in the world by implementing robots into its industries, it has 338 robots per 10.000 employees [8]. Germany's workforce is highly educated and high-skilled professionally. Past couple decades of immigration patterns show waves of immigrants from new at that time the EU member countries. Over 60 percent of all immigrants between 2007 and 2011 were the EU citizens. However, as the initial immigration surge from the EU subsided, Germany is relying on out of the EU immigrants - thirdcountry immigrants to supplement its labor market [21]. According to UN, Germany had over 12 million foreignborn population or about 14.8 percent of the German population in 2015 [9].

Even though Germany is drawing immigrants as a very technologically advanced country, research shows that complicated certification system and limited German language are the main barriers to efficiently take advantage of immigrants' skills and experience [22], [23]. Germany is making progress addressing immigrants' integration into its labor markets by creating formal legislation to ease certification process, but there are informal barriers for immigrants to earn the same wages as natives or move upwards in their career. Estimation is that it takes around 20 
years spent in Germany, having ability to write in German and German degree for an immigrant to fully close the gap in wages [24]. Nevertheless, there are many skilled immigrants that work with the robots in Germany.

\section{Japan}

Japan is very close behind Germany in implementation of industrial robots - it has 327 robots per 10.000 employees [8]. Similar to South Korea, Japan historically is considered monocultural country. However, due to aging population, longtime fertility restrictions and economic development, Japan is experiencing shortage of skilled and low-skilled employees [25]. Therefore, it is making changes in its legislature to attract and admit immigrants. Nevertheless, Japan is still very conservative in admitting immigrants. According to UN, Japan had over 2 million foreign-born population or only about 1.61 percent of the Japan population in 2015 [9]. Majority of foreign-born population is from China, South Korea and Vietnam.

There is wide lobbying for inexpensive foreign skilled workers from small business owners, as they increasingly could not meet demands of local skilled workers towards high wage and benefit packages. On the other hand, there are large corporations that can afford hiring and retaining local skilled workers and, therefore, are more partial to conservative immigration policies [25]. There is very conservative view from the general public on immigration issue - even though public is ready to acknowledge a need for high-skilled workers and their incorporation into Japan's culture, low-skilled workers are looked at as not attuned to the nuances of Japanese culture and very undesirable [26]. As working with robots would require skilled workforce, Japan will likely to immigrate professionals to fill the gap in workforce shortage, but the majority of work will be done by natives.

\section{CONCLUSIONS}

Analysis of four leading countries with the biggest amount of robots per 10.000 employees in the world. Each of the countries that has highest implementation of industrial robots experience shortage of skilled native employees and forecast the shortage to be larger in the future. Even though there is a consensus among all countries regarding a need to fill in the gaps with skilled and high-skilled foreign-born employees, each country has a very different outlook on immigration.

Singapore and Germany rely on immigrants seeking to fulfill labor shortage in their markets. They focus on low and high skilled immigrants, and have developed policies and different forms of visas for immigration.

However, South Korea and Japan have a very low level of immigrants and their main employees are locals. Notwithstanding, these both countries are the most aging countries in the world. Therefore, partners of immigration should be reconsidered. It is a way of Japan to immigrate professionals to fill the gap of digital know-how specialists, which should be followed by South Korea in the near future.
Germany, South Korea and Japan develop many programs for local digital know-how specialists, but none of analyzed countries have programs for immigrants. Therefore, immigrants should be professionals before arrival to enter such robot-based labor-market.

Industry 4.0 changing workforce requirements and countries will have to find a way to either transform their education and vocational training systems to fulfill the need for professionals in new immerging roles or to implement immigration system that is acceptable to both: the counties cultural heritage and economical needs.

\section{REFERENCES}

[1] V. Roblek, M. Meško, \& A. Krapež. A complex view of industry 4.0. Sage Open, 6(2), 2016

[2] W. Schroeder (2016). Germany's Industry 4.0 strategy. London: Friedrich Ebert Stiftung, [Online]. Available: https://www. feslondon. $\quad$ org/fileadmin/user upload/publications/files/FESLondon_Schroeder_Germanys-Industrie-40-Strategy. pdf.

[3] Y. Lu. Industry 4.0: A survey on technologies, applications and open research issues. Journal of Industrial Information Integration, 6, 1-10, 2017.

[4] J. Posada et al. Visual computing as a key enabling technology for industry 4.0 and industrial internet. IEEE computer graphics and applications, 35(2), 26-40, 2015.

[5] M. A. K. Bahrin, M. F. Othman, N. N. Azli, \& M. F. Talib. Industry 4.0: A review on industrial automation and robotic. Jurnal Teknologi, 78(6-13), 137-143, 2016

[6] Digital Skills and Jobs. (2018). The European Commission [online] Available: market/en/policies/digital-skills

[7] Industry 4.0. (2016). European Parliament - Directorate General for Internal Policies, [Online]. Available: http://www.europarl.europa.eu/RegData/etudes/STUD/2016/570007/I POL STU(2016)570007 EN.pdf

[8] S. Wyatt (2019). IFR press conference, [Online]. Available: https://ifr.org/downloads/press2018/IFR\%20World\%20Robotics $\% 20$ Presentation \%20-\%2018\%20Sept $\% 202019$.pdf

[9] International Migrant Stock 2015. United Nations, Department of Population and Social Affairs, [Online]. Available: https://www.un.org/en/development/desa/population/migration/data/e stimates2/estimates15.asp

[10] Robotics Singapore: All You Need to Know about Robotics in Singapore (2020). Global Partners Consulting, [Online]. Available: https://www.gpc-gr.com/robotics-singapore/detail.php?seq=1

[11] E. Lynn-Ee Ho. Negotiating belonging and perceptions of citizenship in a transnational world: Singapore, a cosmopolis? Social \& Cultural Geography, 7(3), 385-401, 2006.

[12] H. Yang, P. Yang, \& S. Zhan. Immigration, population, and foreign workforce in Singapore: An overview of trends, policies, and issues. HSSE Online, 6(1), 10-25, 2017.

[13] M. Zhou, \& H. Liu. Transnational entrepreneurship and immigrant integration: new Chinese immigrants in Singapore and the United States. Immigration and work (Research in the Sociology of Work, vol 27). Emerald Group, 27, 169-201, 2015.

[14] M Baas. The mobile middle: Indian skilled migrants in Singapore and the 'middling' space between migration categories. Transitions: Journal of Transient Migration, 1(1), 47-63, 2017.

[15] B. Oakley (2018). Could Singapore hold the secret to preparing workers for an uncertain future? Ideas.Ted.Com [Online]. Available: https://ideas.ted.com/could-singapore-hold-the-secret-to-preparingworkers-for-an-uncertain-future/

[16] Skillsfuture [Online].

Available: https://www.skillsfuture.sg/credit/trainingproviders

[17] K.F. Lian. International migration and the politics of multiculturalism in Japan, South Korea and Singapore. In International Labour Migration in the Middle East and Asia (pp. 157-175). Springer, Singapore, 2019.

[18] J.H. Ahn. Global migration and the racial project in transition: Institutionalizing racial difference through the discourse of multiculturalism in South Korea. Journal of Multicultural Discourses, 8(1), 29-47, 2013.

[19] M. Quick, V. d'Efilippo (2019). South Korea's Population Paradox. BBC [Online]. Available: https://www.bbc.com/worklife/article/20191010-south-koreaspopulation-paradox 
[20] Evolution and Characteristics of Labour Migration to Korea. (2019) OECD iLibrary [Online]. Available: https://www.oecdilibrary.org/sites/9789264307872-7-

en/index.html?itemId=/content/component/9789264307872-7-en

[21] C. Burkert \& A. Haas. Investing in the future: labor market integration policies for new immigrants in Germany. Washington DC: Migration Policy Institute, 2014

[22] S. Speckesser, S. The immigrant Workforce in Germany: Formal and Informal Barriers to Addressing Skills Deficits. Washington D.C: Migration Policy Institute, 2013.

[23] R. Beyer (2017). The performance of immigrants in the German labor market. SOEPpapers on Multidisciplinary Panel Data Research at DIW Berlin [Online]. Available: https://poseidon01.ssrn.com/delivery.php?ID=4951040010020671170 05065071022118081101069081061084031018005018028083089002 11408210100000302702605411604600301002511203002908910704 80480800090790291120960810830250860390330010961181191160 01100096068013126124120091124126004074119020084107098086 $117096 \& \mathrm{EXT}=\mathrm{pdf}$

[24] O.-J. Kwon. The diverging paths of skilled immigration in Singapore, Japan and Korea: policy priorities and external labor market for skilled foreign workers. Asia Pacific Journal of Human Resources. doi:10.1111/1744-7941.12173, 2018.

[25] R. Dekle (2019) Why Can't Japan Allow Large-Scale Immigration to Solve Labor Shortage Problem? The Globe Post. [Online]. Available: https://theglobepost.com/2019/01/16/japan-labor-shortageimmigrants/

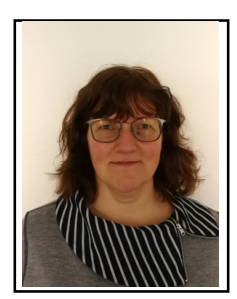

Irma Banevičienė has an MSc in Education from Kaunas University of Technology in Lithuania.

She has worked as a math teacher in several middle schools in Kaunas county in Lithuania. In 1998-2000 she was principal of Senamiescio Gimnazija in Jonava, Lithuania. In 2003 she emigrated to the United States and since then is working in the private sector in Emeryville, California as an accounting team supervisor. She is currently studying Business Management and Supervision at Laney College in Oakland, CA. Her research interests include business leadership and management, employee well-being and training, and immigrants' adjustment in the US workforce.

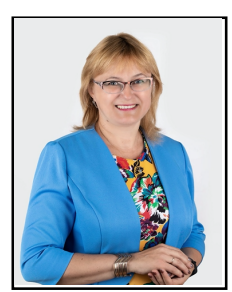

Vilmantè Kumpikaitè-Valiūnienè is a professor of Human Resource Management and a researcher of Digitalization research group, and a head of International Migration Research Centre in School of Economics and Business at Kaunas University of Technology, Lithuania. She worked as an engineer and a consultant in "Telebaltikos konsultacija" in 1998-2002 and a director of educational international company "Cet Baltica" in 2006-2010 in Lithuania. She is an author and co-author of more than 60 scientific publications, a presenter and key-speaker of International conferences around the world. Her research interests include international human resource management, focusing on expatriation and migration, employees' well-being and the role of IT in these processes.

Prof. Kumpikaitè-Valiūnienè is a country representative in European Academy of Management (EURAM) for 2020-2023, a member of Academy of Management (AOM), Academy of International Business (AIB), International Economics Development and Research Center (IERDC), European Group for Organizational Studies (EGOS) and scientific and organizing committee of international conferences. 